\title{
Energiewende and its implications for Germany's energy security
}

\author{
Artur OGUREK, University of Wrocław, Poland \\ Robert KRZEMIEŃ, PWSZ [State Higher School of Vocational \\ Education] in Wałbrzych, Poland \\ Radosław KAMIŃSKI, WSB University in Wrocław, Poland
}

\begin{abstract}
:
Aim: In the 21st century, energy security is one of the most important elements of contemporary politics and economy. The German turn in energy policy is the first attempt on a global scale to move away from nuclear energy to the use of renewable energy (RES -Renewable Energy Sources), albeit with a temporary increase in the use of conventional energy sources (in particular coal). The authors undertook to analyze the course of the German policy turn as well as new opportunities and threats to the stability of its energy system, notably electricity sector.
\end{abstract}

Design / Research methods: In order to analyze the course of the German turn in energy policy as comprehensively as possible, the authors recurred to various studies, often presenting divergent points of view on changes in the German energy industry in recent years. The research process was based on the analysis of the content of the materials subject to consideration.

Conclusions / findings: The analysis carried out shows that the efforts to increase the share of renewable energy will be continued in the near future, while limiting the role of traditional energy sources, with the exception of lignite. The policy will also directly lead to a continued importance of natural gas for the global economy. The changes taking place in the German energy balance to a certain extent limit the country's energy security. This is due to the fact that supplies from wind and solar power plants that are to become dominant in the German energy system are of high volatility and thus constitute a significant threat. Progress in generating energy from renewable sources is not accompanied by similar progress in its storage, and without such storage capacity renewable energy sources will never be stable.

Contact details: Artur OGUREK, ul. Wiejska 69, 47-260 Nieznaszyn; Email: artur.ogurek3@wp.pl, Robert KRZEMIEŃ, ul. Dąbrowskiego 37/5, 58-105 Świdnica; Email: r.-a.-k@wp.pl, Radosław KAMIŃSKI, ul. Łódzka 43/2, 50-521 Wrocław; Email: kaminski.radoslaw@interia.pl

Received: 29.05.2017, Revised: 21.03.2018, Revised: 17.04.2018

doi: http://dx.doi.org/10.29015/cerem.482 


\section{Artur OGUREK, Robert KRZEMIEŃ, Radosław KAMIŃSKI}

Originality / value of the article: The doctrinal assumptions of Energiewende (German energy transition) are fully consistent with the assumptions of the European climate and energy policy, which is also very important from the point of view of Poland. However, attention should be paid to the fact that too rigorous approach to its implementation may - still for a long time - threaten the economy and energy security of Germany and of other European Union states.

Implications: The conducted analysis unambiguously indicates the direction of the energy policy turn in Germany and in other EU states, as well as a change in the way the energy security system operates. The example of Germany, a highly industrialized country seeking to actively participate in the fulfillment of the commitments regarding the international mechanisms designed to combat the climate change, in particular by the transition of its energy sector towards a near zero emission economy, may provide model solutions which could potentially be adopted in other countries.

Limitations of the research: (not applicable)

Key words: energy security, conventional energy, renewable energy sources, sustainable development, energy transition

JEL: $Q 48$

\section{Introduction}

The paper seeks to identify the rationales, aims and objectives of the German energy transition (Energiewende), as the first worldwide attempt to shift away from nuclear energy - toward renewable energy (RES -Renewable Energy Sources), with a temporary increase in the exploitation of conventional heat energy (especially coal-fired energy). Our attempt is to analyze the development of the German energy transition and of the new possibilities as well as threats to the stability of the energy system, in particular, the electricity system. The paper endeavors to use a variety of publications, frequently presenting extremely varied views on the changes conducted in the German power industry over the last years, so as to be able to provide a full picture of this process.

For the German energy policy, implemented in one of the largest economies in the world, the issue of energy security is paramount. This arises from numerous objectified rationales of which one of the most crucial is the enormous demand of the German economy for energy and raw materials necessary in the production of energy. Since Germany is not energy self-sufficient, it has to import some of the energy resources, in particular natural gas and petroleum, and also coal and for this reason the issues of energy security must be considered not only in economic terms 


\section{ENERGIEWENDE AND ITS IMPLICATIONS FOR GERMANY'S ENERGY SECURITY}

but also in those of the state's security policy. Energy security, thus, goes beyond the purely economic sphere.

The issue of Germany's energy security and its energy policy is also crucial for the Polish energy policy and entire economic policy owing to Germany's enjoying a unique position in the EU and Europe, and being Poland's neighbor, and in light of Poland's close economic ties with Germany. The issue goes beyond the question of the two countries functioning within the European chain of domestic fossil fuel production, as well as the external supply of natural gas and petroleum. The German concepts of ensuring the expected level of energy security are influenced by the EU comprehensive energy/climate goals set out until 2020 (European Parliament 2017) and 2030 (European Commission 2017), aimed at reducing greenhouse gas emissions, increasing the share of renewable energy resources in our final energy consumption and improving energy efficiency (European Union 2017). They specify the role of individual economic partners, and, in particular, the supply of hydrocarbon and nuclear fuels, thereby impacting the possibilities in terms of ensuring the level of energy security that is adequate for the economy and of diversity of energy resources. It is therefore worth viewing the issue of energy security through several dimensions (Wüstenhagen, Bilcharz 2006: 1690).

The concept of Energiewende has influenced the form and the implementation pace of Germany's energy policy, creating a completely new situation which - at least indirectly - determines the actions of the other European and non-European countries. Despite the initial doubts and even clear objections voiced by the German public against the concept, the path towards saving energy resources and energy has been firmly established in the mainstream of the German economic policy, and it has, so far, been fairly consistently realized, although not without turbulences. The consensus shared by the public, political parties and even by some economic interest groups is that the energy sector needs to be transformed in order to be more efficient and economically productive, while causing less pollution, and therefore it has to be based on renewable energy sources, although there is still much debate as to the extent and scale of those changes (Hadberg 2017: 4).

For more than a decade, Germany has been "transforming" its energy system, opting for slowly phasing-out nuclear energy, mining of coal and burning it in 


\section{Artur OGUREK, Robert KRZEMIEŃ, Radosław KAMIŃSKI}

thermal power stations, while strongly supporting the renewable energy sources, with the country's energy management becoming increasingly more efficient. This ecological policy pursued by Germany received strong support by a substantial portion of the public, political and academic establishment, as well as business groups. Today we can see that the practical aspect of the implementation of the policy, idealistic in its essence, is also showing its less favorable side.

\section{Energiewende in Germany's Energy Policy}

Energy security, essentially deriving from the availability of energy resources at prices which are affordable and acceptable by the public and economy (Morris, Pehnt 2014: 14), should be a strategic goal for every nation. Energy is a strategic product for all the world's countries, which means that there is a close interaction between the energy consumption level, or the size of energy resources, and the economic development of societies. Thus, ensuring energy production is one of the priorities of every government, with the power industry providing the base on which all modern economies are based. The methods devised to ensure this security are as diverse as the structures of economies and natural resources, and therefore we cannot talk about one universal method to be applied. Every country should establish this security in accordance with its external and internal conditions (Czerpak 2006: 121).

In today's Germany, one of the ways aimed at finding the country's own strategy of energy security is Energiewende (which means energy transition or energy turning point), whose goal is to ensure Germany's energy security through constructing a sound energy supply system, based on all available sources, including those left up to so called commercial power industry, which produces energy on a huge scale, as well as individual, dispersed resources (Starościk 2014: 38). What it essentially implies is that there is "a shift, supervised politically by the state, away from fossil and nuclear fuels to renewable energy sources" (Malko 2014: 6).

This strategy has its roots in the 1980', while the further analysis of the Energiewende concept allows for asserting that its creators proposed a holistic 


\section{ENERGIEWENDE AND ITS IMPLICATIONS FOR GERMANY'S ENERGY SECURITY}

vision with renewable energy and higher energy efficiency taking its center stage (Księżniakiewicz 2015: 174). The term Energiewende itself was first used in 1982 in the title of a scientific analysis conducted by the Institute of Applied Ecology in Freiburg (Bajczuk 2014: 10). It is at that time that the revolutionary thesis was advanced, probably for the first time ever, that economic growth did not have to go hand in hand with increased energy consumption (Morris, Pehnt 2014: 57). In the analysis, the scientists proposed to abandon nuclear energy and petroleum and use, in equal portion, energy generated by coal and renewable sources so as to meet Germany's energy demand by the year 2030. Energy consumption was supposed to fall by $60 \%$ in 2030 , compared to 1973 , that is, by approximately $0,9 \%$ annually. From today's perspective, these are not excessive goals at all, yet at that time it marked a great breakthrough, allowing the ideas of green movements to gradually permeate the political mainstream (Bajczuk 2014: 10). Meanwhile, the need to save energy started to be promoted, which found its perfect expression in the watchword: "Saving - our best energy source". Passing the Act of 1976 on Energy Saving (Księżniakiewicz 2015: 175) was its practical manifestation.

Today, the term Energiewende is essentially associated with the fundamental change of the country's energy policy in the wake of the accident at the Japanese nuclear plant Fukushima on 11 March 2011, as the decision was made to accelerate the process of full denuclearization of Germany by 2022 (Malko 2014: 6), although this is - in some sense - rather far-reaching simplification

\section{Energiewende as a Strategic Initiative}

Energiewende was implemented by adopting on 28 September 2010 the development strategy for the country's energy sector until 2050 (Energiekonzept) (Kamiński 2010: 2) and by having adopted, in 2011, a variety of laws aimed at accelerating the implementation of this long term plan (Bajczuk 2014: 10). In medium and long term, this means a package of applicable laws introducing profound changes in the German power industry, and, in particular, gradual phasingout of nuclear power plants with the consistent development of renewable energy 


\section{Artur OGUREK, Robert KRZEMIEŃ, Radosław KAMIŃSKI}

(Kwiatkowska - Drożdż 2012: 5). The focal point of the strategy is to fulfill most of the energy needs by using renewable energy sources by 2050 (Bajczuk 2014: 8).

The German energy strategy arises from the previous positive experiences with RES and it is also underpinned by numerous analyses and science consultations on the basis of which the decision was made that this was the best direction for Germany's socio-economic development (Bajczuk 2014: 11). According to the strategy, one of the greatest challenges of the 21 century is to ensure "reliable, affordable, environmentally sound and competitive energy supply." The main goals of the new energy strategy, as an element of energy policy and more broadly -of the economic policy, have been (Kamiński 2010: 2):

- climate protection and environment preservation, and limiting climate changes;

- stimulation of technology innovation and "green" economics;

- increasing energy efficiency and decreasing the intensity of the economy;

- increasing economic efficiency of energy undertakings;

- security of energy resources and reduction of the energy products import.

The primary goals of the new strategy have been (Kamiński 2010: 2):

- reduction of the thermal power stations share, especially those using coal;

- extending the service life of nuclear reactors;

- expanding renewable energy sources, especially photovoltaic and wind energy, but also increasing energy production from biomass and the share of other RES technologies;

- development of energy networks and storing energy.

In terms of volume, the goals set out by Germany by 2050, include in particular (Starościk 2014: 38):

- green house gas emissions reduction from 80 to $95 \%$, in relation to the level from the year 1990;

- primary energy consumption smaller by $50 \%$;

- electricity consumption smaller by $25 \%$;

- demand for primary energy in buildings lower by $80 \%$;

- renewable energy sources share in the gross electricity consumption at the level of $80 \%$. 


\section{ENERGIEWENDE AND ITS IMPLICATIONS FOR GERMANY'S ENERGY SECURITY}

- Nowadays, Energiewende, after implementing the changes in 2011, encompasses (Malko 2014: 6):

- reduction and elimination of risk related to nuclear energy plants;

- strengthening the country's energy security by flexible production of electricity.

The three most important and interdependent goals of Energiewende, in line with the strategy provisions, include sustaining competitive energy prices and high living standards, as well as environmental protection (Bajczuk 2014: 11).

The strategy which was adopted in 2010 and modified in 2011, was the first program of the comprehensive change of the German energy sector since 2002, encompassing not only the issues of electricity and heat production, and their supply but also the consumption of energy resources in transport (Kwiatkowska - Drożdż 2012: 7). The challenges of the implementation of the Energiewende concept involve having to cover (with no limits) the country's energy demands while meeting the climate objectives, which means that Germany must face a substantial technological challenge with its citizens and economy having to shoulder some burden which at times could be substantial.

One of the primary aims of the German energy transition is the development of renewable energy sources (Bajczuk 2014: 7), as they are the only ones which neither endanger the environment nor generate carbon dioxide (Bajczuk 2014: 10). However, this is not the only goal. The strategy also seeks to increase energy efficiency, which ultimately will reduce $\mathrm{CO} 2$ emissions. The measures intended for the increased energy efficiency, through building insulation in buildings or redesigning the transport systems, are, however, being carried out at a much slower pace, which mainly results from the government strategy and the system of law, as they prefer investments in new generation capacities at the expense of other projects focusing on energy efficiency (Bajczuk 2014: 7).

Therefore, in the future, increasing energy efficiency, including the redevelopment of the heat market will be the issue that cannot be neglected in the German energy policy, for it will co-determine whether the energy strategy of Energiewende will be successful. The strategic goal in this case is to make climateneutral building resources possible for use by 2050; to this end, the volume of 


\section{Artur OGUREK, Robert KRZEMIEŃ, Radosław KAMIŃSKI}

energy needed for buildings to be operated has to be reduced and renewable energy sources have to be used to generate the heat they need.

For the development of new RES which tend to be scattered, it is necessary to expand grid, both transmission and distribution electricity lines (Kwiatkowska Drożdż 2012: 34). In order to achieve this, a master plan of the energy infrastructure development was created. Apart from constructing new electricity transmission lines, it is, however, necessary to modernize the lines already in place, which often proves to be equally expensive (Bilanz zu Energiewende 2015: 8). That is why, $2.800 \mathrm{~km}$ of new transmission lines are to be constructed by 2022 , with $2.900 \mathrm{~km}$ being scheduled for modernization. These investments will largely be carried out within the area of western Germany, with only one large investment in eastern Länder, it being the construction of a new line between Bärwalede and Schmölln (Bilanz zu Energiewende 2015: 8). The scale of investments in energy lines is enormous, as it ranged between EUR 2,6 and 4 billion alone over the period of 2007-2014 (Zweiter Monitoring-Bericht 2014: 60). These immense costs arise from a number of requirements which have to be met for the investments to be concluded. A stable energy network is important not only for large but also for small power stations generating electricity from RES.

The consistent efforts aimed at supporting innovation are crucial for the success of Energiewende. What is in particular important in this respect is finding smart solutions in terms of improving energy efficiency, energy-saving, development of renewable energy sources, energy storage and systems of power supply and transmission (Starościk 2014 40). Thus, Germany is currently experiencing the process of a profound transformation of the energy sector, with a transition pace which is unprecedented for other developed countries.

\section{Structural Changes of German Power Industry}

The unique nature of the German energy market is attributable to its historical circumstances, particularly, the structure of the energy system operators. Before launching the energy sector transition, there were three regional monopolists in 


\section{ENERGIEWENDE AND ITS IMPLICATIONS FOR GERMANY'S ENERGY SECURITY}

Germany, unlike in other European countries, where typically there was only one energy entity, vertically integrated (Kochanek 2012: 150).

The adoption by the German government of the Energy Act on 28 April 1998 marked the beginning of the changes unfolding on the energy market of our western neighbor. At the same time a full liberalization of the energy market took place, with no transitional periods. Despite the changes implemented in the energy sector, the current structure of the German market in terms of energy production is similar to that established before the reform. There are still vertically integrated entities holding a dominant market position; in addition to the three energy entities which were operating before the transition (E.ON, RWE, EnBW), in 2002 another important entity emerged - Vattenfall Europe, set up by the merger of the following companies: Bewag, H EW, Laubag and VEAG (Kochanek 2012: 150).

The structure of the German energy balance continues to be characterized by a high degree of diversification, where the traditional energy sources have a substantial share - coal, lignite, natural gas, petroleum, as well as unconventional sources - nuclear energy, and also renewable energy (Frączek 2015: 493). Maintaining that diversified structure of primary energy sources considerably increases the country's energy security, for it reduces dependence on individual energy sources, limiting the potential impact on the German energy market of changes on the markets of different energy resources

The dynamics of the changes in the structure of the primary energy sources increased along with the adoption by the German government of the goals of the country's new energy policy (Energiewende 2015) by 2050. Pursuant to the policy of 2010, the future structure of the primary energy sources was supposed to be based on petroleum, natural gas, nuclear energy and renewable energy sources, while reducing the share of coal in the country's energy balance (Frączek 2015: 494). Yet, in 2011, the decision was made to ultimately abandon nuclear energy, which changed radically the future of the entire German energy system.

\subsection{Nuclear Energy}

At the turn of the 20th century, the Federal Republic of Germany, next to the United States, France and Japan, was a powerful global player in the development of 


\section{Artur OGUREK, Robert KRZEMIEŃ, Radosław KAMIŃSKI}

nuclear technologies (Kuźniarski 2011: 2). Although over the 1990', following the Chernobyl accident, the informal moratorium concerning the construction of new reactors was in force, this sector held a very strong position in the German energy market. This cheap source of energy provided by nuclear power plants enabled the German economy to sustain its competitiveness against other EU economies (Kuźniarski 2011: 4). Still, the first protest against nuclear energy, which was the protest against the plan to construct a nuclear power plant in Wyhl, Germany, took place already in 1973 (Księżniakiewicz 2015: 174). Those protests were the reason why even a decade later in 1983 the decision was made to postpone indefinitely the plan to build a nuclear power plant in Baden-Württemberg.

In the 1980', the issue of environmental protection, especially in the context of the energy policy pursued, was dominated by the discussion on nuclear energy and its target role in the German economy, with the basis for the discussion being provided by the report of the Bundestag commission, which was made public and was concerned with the goals of energy policy, including the use of nuclear energy (Księżniakiewicz 2015: 175).

In 2002, the decision was made for the first time in Germany to shut down nuclear power plants by 2021 (Berg 2011). However, in 2010 the period of phasingout the nuclear power plants was extended by 2036 (Księżniakiewicz 2014: 415). The analysis, conducted in 2010, of the impact the extension of the nuclear energy exploitation period would have on electricity prices found that the extension of the operating lifetime of all the then still working nuclear blocks up to 60 years would lead to household energy prices being lower by $16 \%$ in 2030 than would be the case if the extension was not to take place, while the electricity bills paid by the German industry would be lower by 22\% (Kuźniarski 2011: 7).

The expectations with respect to the structure of primary energy sources were redefined following the disaster in the Japanese nuclear plant in Fukushima (Ancygier 2013: 4). This incidence led, however, to yet another radical turn in the German energy policy, impacting fundamentally the way Germany's energy security was perceived (Księżniakiewicz 2014: 415). What followed were changes in the energy policy in all its aspects, that is, its technological, political and economic structure (Frączek 2015: 495). 


\section{ENERGIEWENDE AND ITS IMPLICATIONS FOR GERMANY'S ENERGY SECURITY}

The change of the technological structure in the wake of the nuclear disaster involved the government's decision to implement changes in the German nuclear law and to shut down all German nuclear reactors by 2022, which means that the electricity supply to end-users is no longer reliable, for nuclear reactors ensure stable energy supply whatever the weather conditions, be it lack of wind or sunshine (Frączek 2015: 495).

Abandoning energy based on the atom makes one search for new, cheaper energy sources which do not involve taking great financial and ecological risk. The renewable energy sources seemed to be just the right solution, until recently.

\subsection{Renewable Energy Sources}

Today, the core of the Energiewende concept is the exploitation of renewable energy sources, mainly wind and solar power, where Germany has been the undisputable leader (Kwinta 2009: 26), as well as hydropower (Leszczyński 2009: 76), although it is no longer necessary to have the concept based mainly on the maximum increase of the RES share in the country's energy balance (Frączek 2015: 494). Although Germany's ambitious plan envisages generating electricity from RES at $80 \%$ by 2050 (Molo 2013: 191), it also appreciates - as transient- other conventional resources.

The end of the 20 century and the first decade of this century saw a particularly rapid increase of the RES share (Frączek 2015: 494). Renewable energy sources have been recognized as strategic, for they are the sources which limit Germany's dependence on energy and energy resources import, which makes the country less vulnerable to growing prices of fossil fuels and the policies of foreign suppliers (Morris, Pehnt 2014: 14). Other advantages of the renewable sources are not that difficult to identify: they are virtually emission-free, while accessing them is likely to be of no limits (Starościk 2014: 39). Nor should one forget the benefits arising from the development of renewable energy in Germany as new jobs are being created while the import costs of fossil fuels are reduced (Ancygier 2013: 2).

Unfortunately, one should bear in mind that today the access to solar or wind power, although being of no limit, is irregular over time. The production of energy from wind or the sun is dependent on weather factors beyond our control, which can 


\section{Artur OGUREK, Robert KRZEMIEŃ, Radosław KAMIŃSKI}

be reflected in varying energy generation levels, either lower or substantially higher than current energy demand (Polska. Z energią działa lepiej 2015: 44). That is why, the works focusing on the methods of storing this energy continue seeking to eliminate those irregularities (Starościk 2014: 39). Until then it is not, and most likely it will not be a stable energy source, and therefore, neither reliable nor secure. The high prices of electricity from the renewable energy sources force Germans to rethink the issue of energy provision using other than the already present sources.

This form of energy production would not have been possible but for the relevant regulations of law. As early as in 1991, the German government passed the act regulating the rules for supplying electricity to grid, which clearly favored the producers of the so called green energy (Kochanek 2012: 152). However, the real breakthrough came with the Act on RES of 1 April 2000 giving absolute priority to renewable energy; since then, this act has been a key legal instrument supporting the development of renewable energy sources (Starościk 2014: 39). It obliged the owners of energy networks to purchase green electricity at the producer prices, guaranteed for 20 years and, in addition, much higher than the market prices (Starościk 2014: 39), with the energy generated by RES taking priority over all other energy sources, while those investing in renewable energy were supposed to be compensated for the expenses incurred, with the compensation amount being independent of the electricity prices on the power exchange (Morris, Pehnt 2014: 38). In terms of organization, it is hindered in that there is no centralized market regulator in Germany and so the applicable rules on the access to the grid are those which are negotiated (Fornalczyk 2009: 22).

The implementation of the RSE Act was a real trigger to the energy revolution, with wind and solar energy, and partially also hydro and biomass energy, becoming an important element of the energy balance.

Since then, there have been a few amendments to the act aimed at matching the level of support for RSE to the results obtained in terms of the development of this sector. Even the latest valid amendment of the German law on renewable energy, which became effective in January 2012, failed to account for a substantial fall in the photovoltaic panels prices, which - while the level of the tariffs has remained very high - considerably increased the profitability of solar energy investments 


\section{ENERGIEWENDE AND ITS IMPLICATIONS FOR GERMANY'S ENERGY SECURITY}

(Ancygier 2013: 4). It reduces the costs related to the RES support, even though only partially, which, after all, proved to be too high even for one of the world's most wealthy nations; this, however, does not mean that Germany is withdrawing from the RES development (Starościk 2014: 39). The change in the German energy strategy is aimed solely at reducing the costs, while ensuring further RES development, although this time based more on market terms.

The rapid growth of RSE involves challenges and problems which may slow down the implementation of the long-term energy strategy. The biggest problem is caused by the too quick and too high increase of costs of financing the RES support system. On top of that, increasing the production of energy from RES changes the conditions of competition on the German energy market and necessitates the development of electrical grid. Although the growing supply of renewable energy leveled out the price fluctuations on the power exchange, yet it changed the business model for the entire industry with many power plants, which used to sell energy during peak demand periods, being no longer profitable (Bajczuk 2014: 7).

The growing costs of funding the development of renewable energy gave rise to a debate on possible changes of the support measures for its development. The ever wider use of the expensive and much subsidized wind and solar energy affects the electricity prices, and by inference the competitiveness of the economy (Kuźniarski 2011: 4). The German taxpayers are not burdened with the operation costs of nuclear energy or conventional energy, yet they pay an enormous price for the functioning of the economically ineffective RES sector (Kuźniarski 2011: 7).

The grid operators are required to purchase energy from RES, paying for it high and non-market rates, and yet this energy so often proves to be unsuitable to power large industrial equipment, which - combined with its high costs and unpredictable supply - makes it useless for the industry, therefore being referred to as "trashy energy". Moreover, considering the fact that the conventional power plants need to operate on an ongoing basis in the background of renewable energy, and since they start off slowly and have to work even when the wind turbines generate electricity, renewable energy leads to losses on the part of other energy producers who compensate them by raising prices and passing the higher costs on end- users, that is, households and enterprises (Kuźniarski 2011: 7). 


\section{Artur OGUREK, Robert KRZEMIEŃ, Radosław KAMIŃSKI}

The shift of Germany's energy policy towards a far-reaching dominance of RES is turning into a curse for some of German entrepreneurs. The fear was that abandoning nuclear energy would contribute to energy shortages, yet the problem proved to be quite the opposite because the country is facing overproduction of wind and solar energy, thus making the market oversaturated (Sobański 2013: 58). On the other hand, without stable sources of energy such as nuclear and thermal power plants, or for that matter, coal or natural gas-fired power plants, a larger-scale development of wind farms and photovoltaic installations is not possible, for that would lead to destabilization of the entire electricity system and temporary electricity switch-offs across whole Germany (Kuźniarski 2011: 7).

The rapid development of RES brings about also negative consequences for the electricity transmission and distribution lines which lag behind the RES development, both in Germany and in the electricity systems of its neighboring countries. Clearly acting for the benefit of Germany's energy security, the transmission system operator located there is increasingly more frequently forced to give an instruction to stop the production from RES installations. A growing concern has been the increased problem of the so called cycle flows, i.e. unscheduled electricity flows between the neighboring energy systems. They emerge as a result of a rapid increase in the production of energy from generation installations in one energy system which this system is not capable of transmitting to consumers on its own and which may cause serious congestion and systemic limitations at its neighbors (Polska. Z energią działa lepiej 2015: 44).

Thus, for the RES development to be sustained it is necessary to reduce the costs of the RES support, to create stable conditions for their integration with the whole energy market, to expand the infrastructure and to coordinate actions with the other EU countries (Bajczuk 2014: 7). Those, however, are not and will not be easy undertakings. The development of energy generated from RES in Germany is partially linked to the requirements of the EU law and basically it follows the EU energy policy whose aim is the ever larger share of renewable energy; however, the main barrier to the reforms are the interests of the big business concentrated around the renewable energy. Moreover, Germany has political and economic interests in the development of this sector, for their share in the global market of green 


\section{ENERGIEWENDE AND ITS IMPLICATIONS FOR GERMANY'S ENERGY SECURITY}

technologies is the greatest (approximately 15,2\%), thus ranking the country ahead of China (around 15\%), the USA (around 10\%) and Japan and Italy (around 6\%, respectively) (Bajczuk 2014: 7).

The lack of price competitiveness with respect to RES is a substantial barrier to the development of the German industry, hence the plans to reduce the subsidies for the renewable energy sources and in particular to reduce significantly the fixed tariffs mainly for the barely effective photovoltaic technology (Ancygier 2013: 4). The German government wants to hold back the pace at which the costs are growing through the stable support system - continuous degressivity of the level of support resulting from the development pace of installations drawing on the RES technologies is envisaged for all those technologies (Starościk 2014: 39).

Already in 2014 Bundestag decided to amend the Act on Renewable Energy Sources, restricting the support for the RES development (Polska. Z energia działa lepiej 2015: 45). The reasons for those measures included, among other things, the desire to reduce the growth dynamics of the RES support costs incurred by endusers in their electricity bills. In the future, new installations, especially those relatively large, generating power of over 5MW, should be completely market oriented (Starościk 2014: 39). After the time of such strong support for RES through the system of tariffs guaranteed for prosumer installations only the coming years will, however, show whether this will mark the beginning of a change of the direction of the energy policy pursued by our neighbors to the west.

An important, and very positive area of change within the energy policy will be the reduction of the electricity price growth dynamics for end-users resulting from having to finance the subsidies for the green energy (Frączek 2015: 496). Also, monitoring will be conducted annually to check whether the strategic goals set have been achieved, with a particular role, as decision-making criteria, played by such factors as optimization of energy generation costs, the development of distribution and transmission lines, ensuring energy reserves and integration of the German power industry with the European power market.

Despite the fast development pace of RES in Germany, it is difficult to expect that the renewable energy sources will be able to replace nuclear energy as well as the conventional energy sources. In propagating RES what is required is to ensure 


\section{Artur OGUREK, Robert KRZEMIEŃ, Radosław KAMIŃSKI}

access to other conventional energy sources which would complement the production of electricity, for example, at those times of the day when electricity generated by solar panels or wind power stations is not sufficient (Frączek 2015: 496).

\subsection{Conventional Heat Energy}

Energiewende has been criticized by some of the industry representatives and energy sector as they are not entirely accepting the changes unfolding (Piszczatowska 2014), with the main objection being the enormous costs of the energy transition. The reason why German conventional power plants are facing problems is the energy policy announced in the wake of the accident at Fukushima nuclear plant. Shutting down the oldest nuclear power plants and generous subsidies granted to the renewable energy sources changed completely the picture of the energy market in Germany. The future of large energy companies continues to be a big question mark - their profits are falling and they even incur losses periodically (Zasun 2014, 2015). Power plants generating no profits will have to be closed down unless their work proves to be indispensable for the system (Śmigrowska 2015). Moreover, the option is being considered to make them available to the energy system operators who would pay the owners for using them, yet this will entail a dramatic increase in prices to be paid by the end-users (Zasuń 2014, 2015).

The most advantageous alternative in terms of the environment preservation is to increase the importance of natural gas in the German energy balance; this is because the level of pollution emissions produced from burning this fuel is very low (Śmigrowska 2015a) and it offers great operation flexibility - the production can be increased or reduced within a very short time, barely a dozen or so minutes. The barrier to putting a greater importance on this fuel is, however, the growing uncertainty as to its supply to Germany (Rezygnacja $\mathrm{z}$ atomu 2014) and its high price, compared to that of coal (Frączek 2015: 498). Thus, natural gas is being ousted from the market by coal - both the coal mined in Germany (lignite) (Maćkowiak-Pandera 2015) and the one imported from Russia and the USA (Śmigrowska 2015a). Lignite is the only energy resource that Germany does not have to import, having it in abundance; even if the current production licenses are 


\section{ENERGIEWENDE AND ITS IMPLICATIONS FOR GERMANY'S ENERGY SECURITY}

maintained, the reserves will run out by 2050 at the earliest (Śmigrowska 2015b). The energy groups are thus being induced to invest in new lignite mines, particularly in the former GDR (Węglowa schizofrenia...). That is why coal will be an essential element in the German energy system for many years to come (Kwiatkowska Drożdż 2012: 35). As a result, modern gas-powered stations are being shut down (Energiewende 2.0 2014) while the old and new coal-fired plants are operating at full steam, with the new ones being under construction (Energetyka w Niemczech 2014). The coal-fired power stations are once again becoming an excellent business despite the fact that they are responsible for rising levels of $\mathrm{CO} 2$ emissions, which clearly runs counter to the goals of the German energy policy (Zasun 2014, 2015). Currently, there are over a dozen coal-fired power stations being built in Germany, at a varying degree of progress; in some cases, however, the pace of work has decreased substantially while in other, putting them into service has been delayed (Korzyński 2014).

In 2014, within the German energy mix, the RES share accounted for over $27 \%$, lignite was at $25,6 \%$, coal at $18 \%$, atom at $15,9 \%$, with natural gas being at $9,6 \%$, petroleum at $0,8 \%$ and others at $4,3 \%$ (Energiewende 2015). In 2015 the RES share exceeded $30 \%$, lignite fell to $24 \%$, coal remained at $18 \%$, atom fell to $14 \%$ and natural gas less than $9 \%$ (Niemcy produkują... 2015).

The rapid increase in the use of renewable energy sources in the production of electricity should be a key factor in the gradual decline of the importance of coal and lignite (Księżniakiewicz 2014: 416). In Germany, however, it is not possible to depart from conventional energy (Siergiej 2015), at least unless and until the issue of storing or managing energy from RES has not been properly solved. So the conventional energy has been playing a key role in achieving the goals of Energiewende during the transition period- as a "bridging technology", in particular after having shifted away from nuclear energy, for it has to provide for the energy shortages resulting from this situation (Starościk 2014: 39).

Coal-fired and gas-fired power plants will be necessary for many years to come, yet the country needs conventional power stations that are highly efficient and above all - exploitation-flexible and environmentally friendly, that is, installations of high-efficient cogeneration - their share in the energy balance is supposed to 


\section{Artur OGUREK, Robert KRZEMIEŃ, Radosław KAMIŃSKI}

account for 25\% by 2020 (Starościk 2014: 39). Following the scheduled abandoning of mining coal from the country's own reserves, as the German government approved the plan of closing all coal mines by 2018 already in 2007, which was due to the sector's unprofitability (Kochanek 2012: 151), Germany's dependence on the import of energy resources is bound to increase (Frączek 2015: 497). Despite the plans to abandon coal mining, its share will continue to be substantial in the German energy balance, and this will be linked to the increase in the scale of its import. The domestic resource lignite, which is most widely available in Germany and yet harmful in terms of the environment preservation and climate protection may gain even more importance.

\section{Conclusion}

The changes that have been unfolding over the last several decades with respect to Germany's energy policy led to the transformation of the structure of the country's energy balance. The key appears the decision to abandon completely nuclear energy and replace it with other renewable energy sources. There are many indications that over the next years the work focusing on raising the importance of RES will be continued while simultaneously the role of the traditional sources of energy, with the exception of lignite, will be reduced, albeit the rules governing the support measures will be substantially modified and we will see a gradual shift towards the market rules.

The increased importance of RES will also affect natural gas in that its relevance will increase too, since its use in power plants makes it easier to reduce pollution emissions, while being indispensible in increasing capacity in grid at times when less energy is being produced by wind and photovoltaic power stations. In Germany, a small rise in the importance of coal, mainly lignite, in the country's energy balance has been recorded, which is linked to the attempts aimed at replacing nuclear power plants and also trying to take advantage of the fall in coal prices on the global markets offering this fuel. However, what the role of coal and natural gas will look 


\section{ENERGIEWENDE AND ITS IMPLICATIONS FOR GERMANY'S ENERGY SECURITY}

like will be determined by price competitiveness of those energy sources and the reliability of their supplies.

The changes that have been taking place in Germany's energy balance have, so far, affected energy security by having it reduced to some extent as a result of the increased dependence on imported energy resources. A significant threat to Germany's energy security is posed by the volatility of energy supply from wind and solar power stations, which are to dominate the energy system. The progress made in terms of energy generation from renewable energy sources is not accompanied by the same progress in terms of its storing and yet this is necessary for those sources to be stable.

In order to make the supply of energy resources more secure, Germany is taking measures aimed at tailoring the structure of energy balance to current market needs which, among other things, involve - even though only temporary - supporting coalfired installations, mainly using lignite mined domestically, as the most stable resources. While the doctrinaire goals of Energiewende are fully in line with the goals of the European climate/energy policy, they - too rigorously implemented are likely to threaten German economy and the country's energy security still for a long time.

\section{References}

Ancygier A. (2013), Rozwój energii odnawialnych w Niemczech i w Polsce: Marsz w przeciwnych kierunkach?, [, Renewable Energy Development in Germany and Poland: Marching in Opposite Directions?'] Biuletyn Niemiecki, no 34

Bajczuk R. (2014), Odnawialne źródła energii w Niemczech. Obecny stan rozwoju, grupy interesu i wyzwania, Raport Ośrodka Studiów Wschodnich [Renewable Energy Sources in Germany. The Current State of Development, Stakeholders and Challenges, a Report by the Center for Eastern Studies], Warszawa

Berg P. (2011), Koniec ery atomu. Niemcy zamkną elektrownie jądrowe [The End of the Nuclear Age. Germany to Close down Nuclear Power Stations], www.polityka.pl/ tygodnikpolityka/swiat/1516372,1,niemcy-zamkna-elektrownie-jadrowe.read. [17.01.2017]

Bilanz zu Energiewende (2015), Berlin 


\section{Artur OGUREK, Robert KRZEMIEŃ, Radosław KAMIŃSKI}

Czerpak P. (2006), Bezpieczeństwo energetyczne [Energy Security], in: K. Żukrowska, M. Grącik (ed.), Bezpieczeństwo międzynarodowe. Teoria i praktyka [Global Security. Theory and Practice], Warszawa

Energetyka w Niemczech (2014), Coraz więcej prądu z węgla, głównie amerykańskiego [Power Industry in Germany. More and More Electricity Generated Mainly by the U.S. Coal], portal Money, http://www.money.pl/gospodarka/uniaeuropejska/wiadomosci/artykul/energetyka;w;niemczech;coraz;wiecej;pradu;z;wegla;glowni e;amerykanskiego,14,0,1590542.html [10.02.2017]

Energiewende 2.0 - postulaty dla pomyślnej kontynuacji transformacji energetycznej [Energiewende 2.0 - Proposals for a Successful Continuation of the Energy Transition] (2014), http://www.chronmyklimat.pl/wiadomosci/energetyka/energiewende-20-postulatydla-pomyslnej-kontynuacji-transformacji-energetycznej [31.01.2017]

Energiewende: OZE najważniejszym źródłem energii w Niemczech [Energiewende: RES as the Most Important Source of Energy for Germany] (2015), http://www.chronmyklimat.pl/wiadomosci/energetyka/energiewende-oze-najwazniejszymzrodlem-energii-w-niemczech [04.02.2017]

European Union (2017), Ramy polityki w zakresie klimatu i energii do roku 2030 [Climate and Energy Policy ramework until 2030], https://ec.europa.eu/clima/policies/strategies/2030_pl [12.02.2017]

European Union (2017), Energia, https://europa.eu/european-union/topics/energy_pl [03.01.2017]

European Parliament (2017), Noty faktograficzne o Unii Europejskiej [Factual Notes on the European Union], http://www.europarl.europa.eu/atyourservice/pl/displayFtu.html?ftuId=FTU_5.7.1.html [05.01.2017]

Hadberg A. (2017), Germany's energy transition: making it deliver, European Policy Centre, Discussion $\quad$ Paper $\quad 9 \quad$ October 2017 , http://www.epc.eu/documents/uploads/pub_7997_germanyenergytransition.pdf [03.04.2018]

Fornalczyk T. (2009), Rynek energii w Niemczech [Energy Market in Germany], Polska Energia, no 1

Frączek P. (2015), Uwarunkowania bezpieczeństwa energetycznego Niemiec [Determinants of Energy Security in Germany], Nierówności Społeczne a Wzrost Gospodarczy, no 1 (41)

Kamiński S. (2010), Analiza BBN nt. nowej strategii energetycznej Republiki Federalnej Niemiec [Polish NSB Analysis on Geramny's New Energy Strategy], Warszawa 


\section{ENERGIEWENDE AND ITS IMPLICATIONS FOR GERMANY'S ENERGY SECURITY}

Kochanek E. (2012), System bezpieczeństwa energetycznego Republiki Federalnej Niemiec [Germany’s Energy Security System], Energetyka marzec-kwiecień 2012

Korzyński M. (2014), Niemiecka polityka klimatyczna [German Climate Policy], http://www.chronmyklimat.pl/wiadomosci/energetyka/niemiecka-polityka-klimatyczna [01.02.2017]

Księżniakiewicz M. (2014), Bezpieczeństwo energetyczne Unii Europejskiej a polityka energetyczna Francji i Niemiec, (The EU Energy Security and Energy Policy of France and Germany] Rocznik Integracji Europejskiej, no 8

Księżniakiewicz M. (2015), Nowa era w polityce Niemiec w obszarze odnawialnych źródeł energii [A New Age in German RES Policy], Rocznik Bezpieczeństwa Międzynarodowego, vol. 9, no 1

Kuźniarski Ł. (2011), Energetyka jądrowa w Niemczech [Nuclear Energy in Germany], Biuletyn Niemiecki, no 13

Kwiatkowska - Drożdż A. (ed.) (2012), Niemiecka transformacja energetyczna. Trudne początki [German Energy Transition. Difficult Beginnings], Warszawa

Kwinta W. (2009), Dotacje napędzają energetykę słoneczną [Subsidies Drive Solar Power], Nowa Energia, no 6

Leszczyński T. (2009), Hydroenergetyka w Unii Europejskiej [Hydropower in the European Union], Biuletyn Urzędu Regulacji Energetyki, no 6

Maćkowiak-Pandera J. (2015), Dlaczego Niemcy zdecydowali się na Energiewende? [Why Did Germany Choose Energiewende?], http://www.chronmyklimat.pl/wiadomosci/energetyka/dlaczego-niemcy-zdecydowali-sie-naenergiewende [01.02.2017]

Malko J. (2014), ENERGIEWENDE - niemiecka transformacja energetyczna [Energiewende - German Energy Transition], Polityka Energetyczna - Energy Policy Journal, tom 17, zeszyt 2

Molo B. (2013), Polityka bezpieczeństwa energetycznego Niemiec w XXI wieku [Germany's Energy Security Policy in the 21st Century], Kraków

Morris C., Pehnt M. (2014), Niemiecka transformacja energetyczna. Przyszłość oparta na odnawialnych źródłach energii, [German Energy Transition The Future Based on Renewable Energy Sources], Berlin 


\section{Artur OGUREK, Robert KRZEMIEŃ, Radosław KAMIŃSKI}

Niemcy produkują już energię w ponad 30 proc. z OZE [Germany Is Already Producing over 30\% Energy from RES] (2015), http://www.chronmyklimat.pl/wiadomosci/energetyka/niemcy-produkuja-juz-energie-wponad-30-proc-z-oze [30.01.2017]

Piszczatowska J. (2014), Zielona rewolucja w Niemczech idzie pełną parą, [German Green Revolution Going Great Guns] http://wysokienapiecie.pl/energetyka-konwencjonalna/451zielona-rewolucja-w-niemczech-idzie-pelnapara?highlight=YToxOntpOjA7czoxMjoiZW5lcmdpZXdlbmRlIjt9 [14.02.2017]

Polska. Z energią działa lepiej. Energetyka przesyłowa i dystrybucyjna - raport PTPiREE (2015), [With Energy Poland Functions Better. Power Transmission and Distribution - a Report by Polish Power Transmission and Distribution Association], Poznań

Rezygnacja z atomu zwiększy zależność od Rosji? [Will Abandoning Nuclear Power Result in Increased Dependence on Russia?] (2014), http://www.money.pl/gospodarka/wiadomosci/artykul/rezygnacja;z;atomu;zwiekszy;zalezno sc;od;rosji,225,0,1496545.html [19.02.2017]

Siergiej P. (2015), Niemcy i Wielka Brytania - energetyka odnawialna zaczyna dominować [Germany and Great Britain - Renewable Power Industry Is about to Become Dominant], http://www.chronmyklimat.pl/wiadomosci/energetyka/niemcy-i-wielka-brytania-energetykaodnawialna-zaczyna-dominowac [14.01.2017]

Sobański W. (2013), „Energetyczny przełom” będzie drogo Niemców kosztował. Kosztowna zielona rewolucja w energii [Germany Is Going to Pay a High Price for „Energy Breakthough". Expensive Green Revolution in Energy Generation], Rynki Tworzyw wrzesień 2013,

Starościk J. (2014), Energiewende - strategia energetyczna po niemiecku, [Energiewende Energy Strategy in the German Way], Polski Instalator 2014, nr 11-12

Śmigrowska M. (2015b), Koncerny energetyczne w Niemczech: krok do przodu, krok do tyłu, [Energy Corporations in Germany: One Step Forward, One Step Back] http://www.chronmyklimat.pl/wiadomosci/energetyka/koncerny-energetyczne-w-niemczechkrok-do-przodu-krok-do-tylu [05.01.2017]

Śmigrowska M. (2015), Niemcy zmieniają się na naszych oczach - dzięki Energiewende [Germany Is Changing before our Very Eyes -Thanks to Energiewende], http://www.chronmyklimat.pl/wiadomosci/polityka-klimatyczna/niemcy-zmieniaja-sie-nanaszych-oczach-dzieki-energiewende [12.02.2017]

Śmigrowska M. (2015a), Niemcy: czy węgiel zastąpił atom?, [Germany: Has Coal Replaced the Atom?] http://www.chronmyklimat.pl/wiadomosci/polityka-klimatyczna/niemcy-czywegiel-zastapil-atom [30.01.2017] 


\section{ENERGIEWENDE AND ITS IMPLICATIONS FOR GERMANY'S ENERGY SECURITY}

Węglowa schizofrenia Niemiec [Germany's Coal Schizophrenia] (2014), http://www.elektroonline.pl/news/7770,Weglowa-schizofrenia-Niemiec [13.01.2017]

Wüstenhagen R., Bilharz M. (2006), Green energy market development in Germany: effective public policy and emerging customer demand, Energy Policy, no 34, https://pdfs.semanticscholar.org/630d/5c24673d9930fbc0e18df16c48c5efbaff3d.pdf [04.04.2018]

Zasuń R., (2014), Niemcy - europejski poligon energetyczny [Germany - a European Test Bed for Energy], http://wysokienapiecie.pl/oze/342-niemcy-europejski-poligonenergetyczny?highlight=YToxOntpOjA7czoxMjoiZW5lcmdpZXdlbmRIIjt9 [14.02.2017]

Zasuń R. (2015), Energetyczne drogi Niemiec i Polski coraz bardziej się rozchodzą [Increasingly Diverging Energy Ways of Germany and Poland], http://www.chronmyklimat.pl/wiadomosci/energetyka/energetyczne-drogi-niemiec-i-polskicoraz-bardziej-sie-rozchodza [31.01.2017]

Zweiter Monitoring-Bericht (2014), „Energie der Zukunft”, Berlin 